\title{
Identification of Compounds from Nigella Sativa as New Potential Inhibitors of 2019 Novel Coronasvirus (Covid-19): Molecular Docking Study
}

\author{
Bouchentouf Salim ${ }^{1,2, *}$ and Missoum Noureddine ${ }^{2,3}$ \\ 1: Facult of Technology, Doctor Tahar Moulay University of Saida, Algeria \\ *bouchentouf.salim@yahoo.fr, salim.bouchentouf@univ-saida.dz \\ 2: Laboratory of Natural products and Bioactives, University of Tlemcen \\ 3: Faculty of Technology, University Hassiba Ben Bouali of Chlef, Algeria
}

\begin{abstract}
The spread of the global COVID-19 pandemic, the lack of specific treatment and the urgent situation requires use of all resources to remedy this scourge. In the present study, using molecular docking, we identify new probable inhibitors of COVID-19 by molecules from Nigella sativa L, which is highly reputed healing herb in North African societies and both Islamic and Christian traditions. The discovery of the $\mathrm{M}^{\text {pro }}$ protease structure in COVID-19 provides a great opportunity to identify potential drug candidates for treatment. Focusing on the main proteases in CoVs $\left(3 \mathrm{CL}^{\text {pro }} / \mathrm{M}^{\text {pro }}\right.$ ) (PDB ID 6LU7 and 2GTB); docking of compounds from Nigella Sativa and drugs under clinical test was performed using Molecular Operating Environment software (MOE). Nigelledine docked into 6LU7 active site gives energy complex about $6.29734373 \mathrm{Kcal} / \mathrm{mol}$ which is close to the energy score given by chloroquine $(-6.2930522 \mathrm{Kcal} / \mathrm{mol})$ and better than energy score given by hydroxychloroquine $(-5.57386112 \mathrm{Kcal} / \mathrm{mol})$ and favipiravir $(-4.23310471$ $\mathrm{kcal} / \mathrm{mol}$ ). Docking into 2GTB active site showed that $\alpha$ - Hederin gives energy score about-6.50204802 $\mathrm{kcal} / \mathrm{mol}$ whcih is better energy score given by chloroquine $(-6.20844936 \mathrm{kcal} / \mathrm{mol})$, hydroxychloroquine ($5.51465893 \mathrm{kcal} / \mathrm{mol})$ ) and favipiravir $(-4.12183571 \mathrm{kcal} / \mathrm{mol})$. Nigellidine and $\alpha$ - Hederin appeared to have the best potential to act as COVID-19 treatment. Further, researches are necessary to testify medicinal use of identified and to encourage preventive use of Nigella Sativa against coronavirus infection.
\end{abstract}

Keywords: COVID-19; Nigella Sativa; 6LU7; 2GTB; molecular docking; MOE software

\section{Introduction}

During December 2019 a novel coronavirus (COVID-19) has been reported from Hubei province in China ${ }^{\mathrm{i}}$. The virus associated with human to human transmission is causing several human infections and disorder not only in the respiratory apparatus but also in the digestive tract and systemically ii iii iv. On March 11, 2020, world health organization characterizes COVID-19 as a pandemic which caused until 30, March, 2020 30,105 death and 638,146 confirmed cases over the world ${ }^{\mathrm{v}}$. Due to gravity of the situation, urgent and complementary efforts from researchers are necessary to find therapeutic agents and new preventive methods. Description of COVID-19 virus shown three important proteins know as papain-like protease $\left(\mathrm{PL}^{\mathrm{pro}}\right)$, 3C-like protease $\left(3 \mathrm{CL}^{\mathrm{pro}}\right)$ and spike protein to be attractive target for drug development ${ }^{\mathrm{vi}}$. Viral polypeptide onto functional proteins is processed by Coronavirus $\mathrm{PL}^{\text {pro }}$ which is also a deubiquitinating

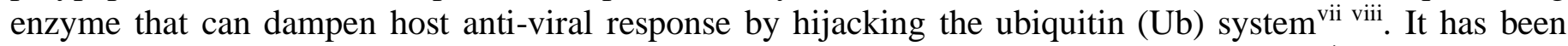
shown also that SARS-3CL ${ }^{\text {pro }}$ is a cysteine protease indispensable to the viral life cycle ${ }^{\text {ix }}$. Angiotensinconverting enzyme 2 (ACE2) is used by Coronavirus spike protein as a receptor to help the virus enter cells ${ }^{x}$. The potential target $\left(\mathrm{M}^{\mathrm{pro}}\right)$ /chymotrypsin-like protease $\left(3 \mathrm{CL}^{\mathrm{pro}}\right)$ from COVID-19 (6LU7) have been successfully crystallized by Liu et al (2020) and repositioned in Protein Data bank (PDB) ${ }^{\mathrm{xi}}$. Medicinal chemists are focusing also on the main protease of SARS-Coronavirus (2GTB) to develop antiviral treatments of the virus causing COVID-19 ${ }^{\text {xii }}$ because it shares $96 \%$ similarity ${ }^{\text {xiii }}$. Some in silico preliminary studies have been conducted to find small molecules from herbal plants with the potential to inhibit 2019 novel coronavirus ${ }^{\text {xiv } x v \text { xvi. }}$. 
Contagious disease treatment and control is widely demonstrated by effectiveness of medicinal herbs ${ }^{\text {xviixviii }}$ xix xx xxi. Absence of specific therapy for COVID-19 leads population over many regions in the world to use medicinal herbs knows in ethnophamacologie as antiviral. In our present study and inspired by recent molecular docking studies xxii xxiii we illustrate interactions between small molecules from North African medicinal herb; Nigella sativa $L$ in order to identify the favorable molecules for COVID-19 treatment and compare them to proposed drugs such as chloroquine hydroxychloroquine,azithromycin, arbidol, remdesivir, and favipiravir ${ }^{\mathrm{xxiv}} \mathrm{xxv}^{\mathrm{x}}$. The in silico study was done using Molecular Operating Environment software $(\mathrm{MOE})^{\mathrm{xxvi}}$. The present study will provide other researchers with important investigation way to identify new COVID-19 treatment and use of natural products.

\section{Material and methods \\ Medicinal herb choice}

Based on local survey we reported that Nigella sativa L. commonly known as black seed or black cumin (Haba sawda) is widely recommended in society during the COVID-19 crisis for their probable antiviral effects. The large traditional use of black cumin as panacea (universal healer) in North African societies came from Islamic belief and also Bible ${ }^{\mathrm{xxvii}}$. Nigella sativa is cited by many research papers for its multiple benefits as antiviral, anti-inflammatory, anti-cancer, analgesic...etc xxviii xxix xxx xxxi.

\section{Preparation of both enzymes and ligands}

Download of $3 \mathrm{cl}^{\text {pro }} / \mathrm{M}^{\text {pro }}$ COVID-19 and $3 \mathrm{c}^{\text {pro }} / \mathrm{M}^{\text {pro }}$ SARS-coronavirus three dimensional structures were done from Protein Data Bank ${ }^{\mathrm{xx} x i i}$ under PDB ID 6LU7 and 2GTB respectively ${ }^{\mathrm{xx} x i i \mathrm{x} x \mathrm{xiv}}$. Crystallographic properties of 6LU7 and 2GTB are reported in table 1. Table 2 reports major chemical compounds of Nigella sativa $L$ collected from literature ${ }^{\operatorname{xxx}} \mathrm{xxxvi}$ xxxvii xxxviii $\mathrm{xxxix} \times{ }^{\mathrm{xl}}$. The 3-dimensional (3D) structures of main chemical compounds from Nigella sativa were downloaded in .sdf format from PubChem ${ }^{\text {xli }}$. Lipinski's physicochemical parameters rule xlii xliii xliv were also studied for each ligand and reported in table 3. Chemical structures of main drugs under clinical tests for treatment of COVID-19 are reported in table $4{ }^{\mathrm{xlv}}$ xlvi xlvii.

Identification of the preferred region of the receptor that interacts with ligands is known by active site prediction and isolation protocol ${ }^{\text {xlviii }}$. Using Hamiltonian AM1 (Austin model 1) implanted in MOE and field strengths in the MMFF94x (Merck molecular force field) energy of the protein was minimized. In addition, water molecules were removed from the protein surface so that the interaction region will not be hidden while docking. By use of site-finder module implanted in MOE, active sites of 6LU7 and 2GTB were identified and shown in figure 1 and 2 respectively. Also both natural ligands (compounds from Nigella sativa $L$ ) and proposed drugs were submitted to energy minimizing under default conditions of temperature $=300^{\circ} \mathrm{K}$ and $\mathrm{pH}=7$.

Table 1: Crystallographic properties of enzymes

\begin{tabular}{|c|c|c|c|c|c|c|c|c|}
\hline Enzyme & $\begin{array}{c}\text { PDB } \\
\text { Code }\end{array}$ & Classification & Organism & $\begin{array}{c}\text { Expression } \\
\text { system }\end{array}$ & Resolution & Method & $\begin{array}{c}\text { Total } \\
\text { structure } \\
\text { weight } \\
\text { (DA) }\end{array}$ & chaine \\
\hline $\begin{array}{c}\text { COVID-19 } \\
\text { main } \\
\text { protease }\end{array}$ & $6 \mathrm{LU7}$ & $\begin{array}{c}\text { VIRAL } \\
\text { PROTEIN }\end{array}$ & $\begin{array}{c}\text { Bat SARS- } \\
\text { like } \\
\text { coronavirus }\end{array}$ & $\begin{array}{c}\text { Escherichia } \\
\text { coli } \\
\text { BL21(DE3) }\end{array}$ & $2.1 \AA$ & X-RAY & 34506.34 & A \\
\hline $\begin{array}{c}\text { SARS } \\
\text { coronavirus } \\
\text { main } \\
\text { peptidase }\end{array}$ & 2GTB & HYDROLASE & $\begin{array}{c}\text { SARS } \\
\text { coronavirus } \\
\text { CUHK-L2 }\end{array}$ & $\begin{array}{c}\text { Escherichia } \\
\text { coli }\end{array}$ & $2 \AA$ & $\begin{array}{c}\text { X-RAY } \\
\text { DIFFRACTION }\end{array}$ & 34649.48 & A \\
\hline
\end{tabular}


Table 2: Chemical structures of major compounds from Nigella Sativa.

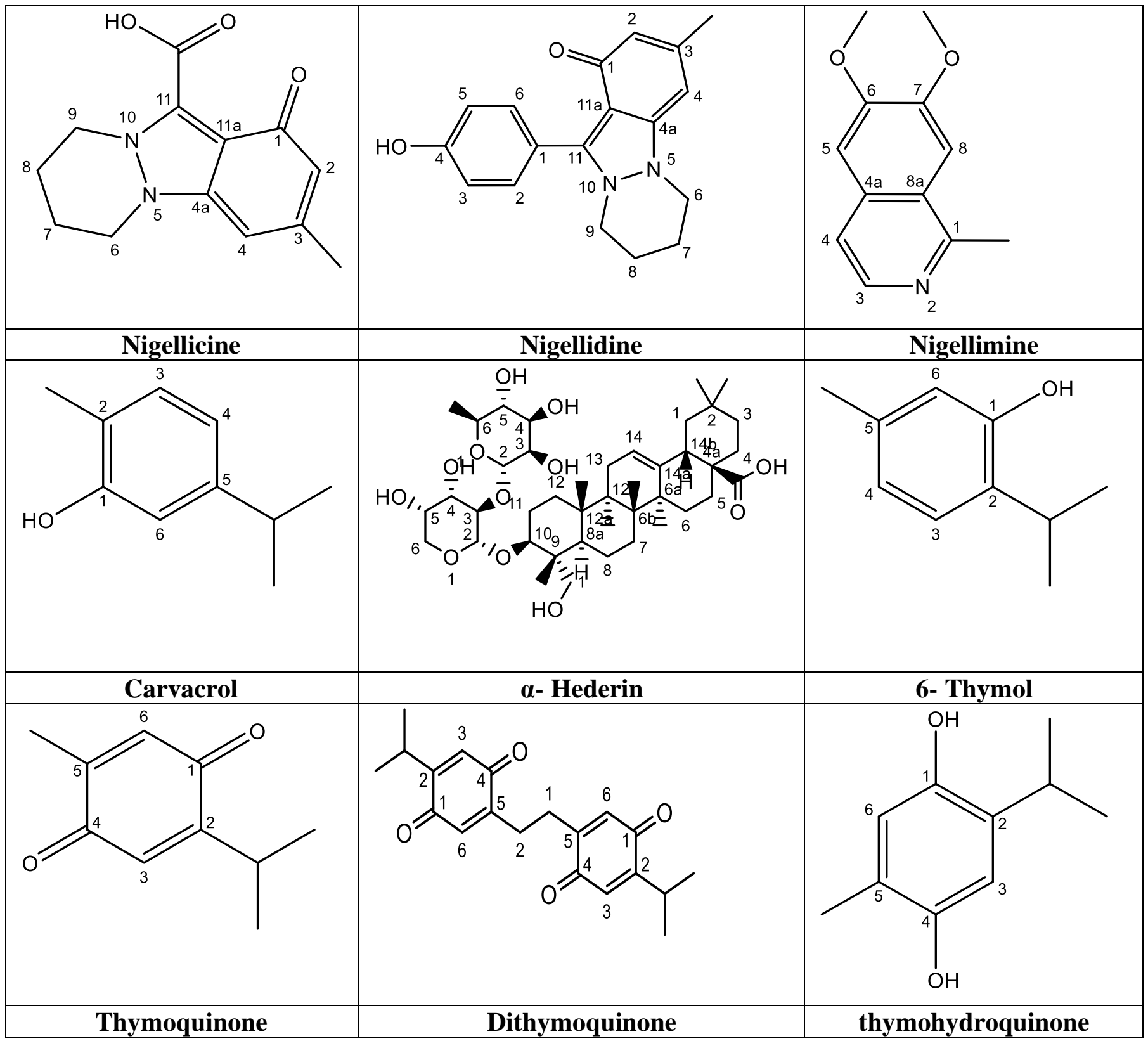

Table 3: Expanded Lipinski's physicochemical parameter for Nigella sativa compounds.

\begin{tabular}{|l|l|l|l|l|l|l|l|l|l|}
\hline $\mathbf{N}^{\circ}$ & \multicolumn{1}{|c|}{ Ligands } & $\begin{array}{c}\text { Molecular } \\
\text { weight } \\
(\mathbf{g} / \mathbf{m o l})\end{array}$ & Toxicity & $\begin{array}{c}\text { Retro } \\
\text { synthese \% }\end{array}$ & Hdonn & Hacc & $\begin{array}{c}\text { Log } \\
\mathbf{P}\end{array}$ & $\begin{array}{c}\text { Log } \\
\mathbf{S}\end{array}$ & $\begin{array}{c}\text { TPSA } \\
\left(\mathbf{A}^{\mathbf{2}}\right)\end{array}$ \\
\hline 1 & Nigellicine & 246.27 & no & 33.33 & 1 & 3 & 1.06 & -2.19 & 60.85 \\
\hline 2 & Nigellidine & 294.35 & no & 100 & 1 & 2 & 2.94 & -3.7 & 43.78 \\
\hline 3 & Nigellimine & 203.24 & no & 100 & 0 & 3 & 2.56 & -2.42 & 31.35 \\
\hline 4 & Carvacrol & 150.22 & no & 100 & 1 & 1 & 2.82 & -2.69 & 20.23 \\
\hline 5 & $\alpha-$ Hederin & 750.97 & no & 35.85 & 7 & 12 & 3.52 & -8.24 & 195.60 \\
\hline 6 & Thymol & 150.22 & no & 100 & 1 & 3 & 2.82 & -2.69 & 20.23 \\
\hline 7 & Thymoquinone & 164.20 & no & 100 & 0 & 2 & 1.67 & -2.48 & 34.14 \\
\hline 8 & Dithymoquinone & 328.41 & no & 0.00 & 0 & 4 & 2.71 & -3.90 & 68.28 \\
\hline 9 & thymohydroquinone & 166.22 & no & 100 & 2 & 2 & 2.53 & -2.01 & 40.46 \\
\hline
\end{tabular}


Table 4: Chemical structures of main proposed drugs for COVID-19 treatment

\begin{tabular}{|c|c|c|c|c|c|}
\hline ligands & Name & Structures & Pub Chem CID & Expanded I & ki's rule \\
\hline \multirow{7}{*}{1} & \multirow{7}{*}{ Chloroquine } & & \multirow{7}{*}{2719} & Properties & Value \\
\hline & & & & $\mathrm{MW}(\mathrm{g} / \mathrm{mol})$ & 320.89 \\
\hline & & & & H-donor & 2 \\
\hline & & & & H-acceptor & 1 \\
\hline & & & & $\log P$ & 3.39 \\
\hline & & & & $\log S$ & -3.76 \\
\hline & & & & TPSA $(\AA)$ & 29.36 \\
\hline \multirow{7}{*}{2} & \multirow{7}{*}{ Hydroxychloroquine } & & \multirow{7}{*}{3652} & Properties & Value \\
\hline & & & & $\mathrm{MW}(\mathrm{g} / \mathrm{mol})$ & 336.89 \\
\hline & & & & H-donor & 3 \\
\hline & & & & H-acceptor & 2 \\
\hline & & & & $\log \mathrm{P}$ & 2.37 \\
\hline & & & & $\log S$ & -3.23 \\
\hline & & & & TPSA $(\AA)$ & 49.59 \\
\hline \multirow{7}{*}{3} & \multirow{7}{*}{ Azythromycine } & & \multirow{7}{*}{447043} & Properties & Value \\
\hline & & & & $\mathrm{MW}(\mathrm{g} / \mathrm{mol})$ & 751.01 \\
\hline & & & & H-donor & 7 \\
\hline & & & & H-acceptor & 11 \\
\hline & & & & $\log P$ & -0.93 \\
\hline & & & & $\log S$ & -3.64 \\
\hline & & & & TPSA $(\AA)$ & 182.48 \\
\hline \multirow{7}{*}{4} & \multirow{7}{*}{ Arbidol } & & \multirow{7}{*}{131411} & Properties & Value \\
\hline & & & & $\mathrm{MW}(\mathrm{g} / \mathrm{mol})$ & 477.42 \\
\hline & & & & H-donor & 1 \\
\hline & & & & H-acceptor & 3 \\
\hline & & & & $\log P$ & 6.07 \\
\hline & & & & $\log S$ & -5.82 \\
\hline & & & & TPSA $(\AA)$ & 54.70 \\
\hline \multirow{7}{*}{5} & \multirow{7}{*}{ Remdesivir } & & \multirow{7}{*}{121304016} & Properties & Value \\
\hline & & & & $\mathrm{MW}(\mathrm{g} / \mathrm{mol})$ & 602.58 \\
\hline & & & & H-donor & 4 \\
\hline & & & & H-acceptor & 10 \\
\hline & & & & $\log \mathrm{P}$ & 1.24 \\
\hline & & & & $\log S$ & -5.17 \\
\hline & & & & TPSA $(\AA)$ & 203.01 \\
\hline \multirow{7}{*}{6} & \multirow{7}{*}{ Favipiravir } & & \multirow{7}{*}{492405} & Properties & Value \\
\hline & & & & $\mathrm{MW}(\mathrm{g} / \mathrm{mol})$ & 157.10 \\
\hline & & & & H-donor & 2 \\
\hline & & & & H-acceptor & 3 \\
\hline & & & & $\log \mathrm{P}$ & -1.19 \\
\hline & & & & $\log S$ & -1.33 \\
\hline & & & & TPSA $(\AA)$ & 84.55 \\
\hline
\end{tabular}




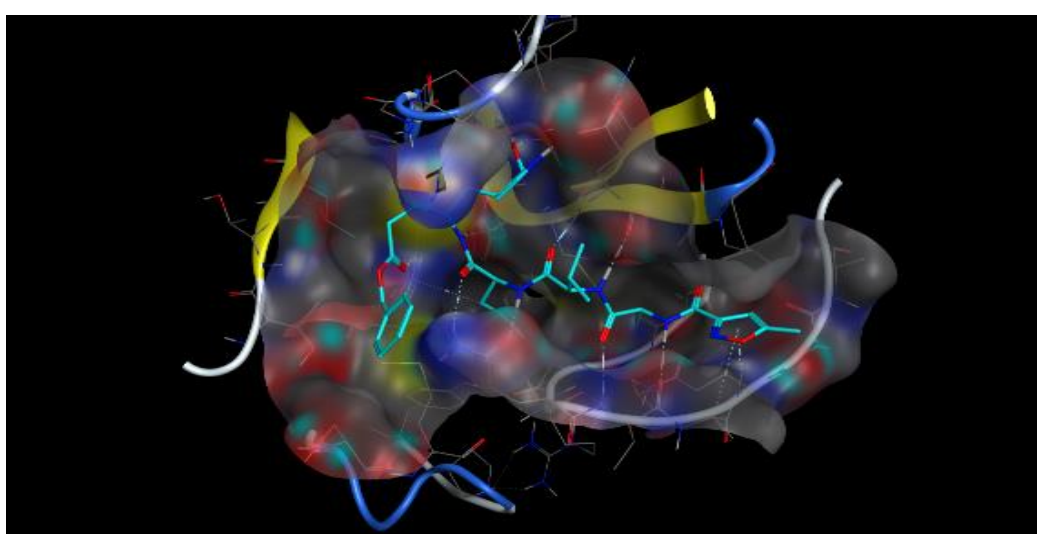

Figure 1: Isolated active site of 6LU7 in complex with an inhibitor N3 (PRD_002214)

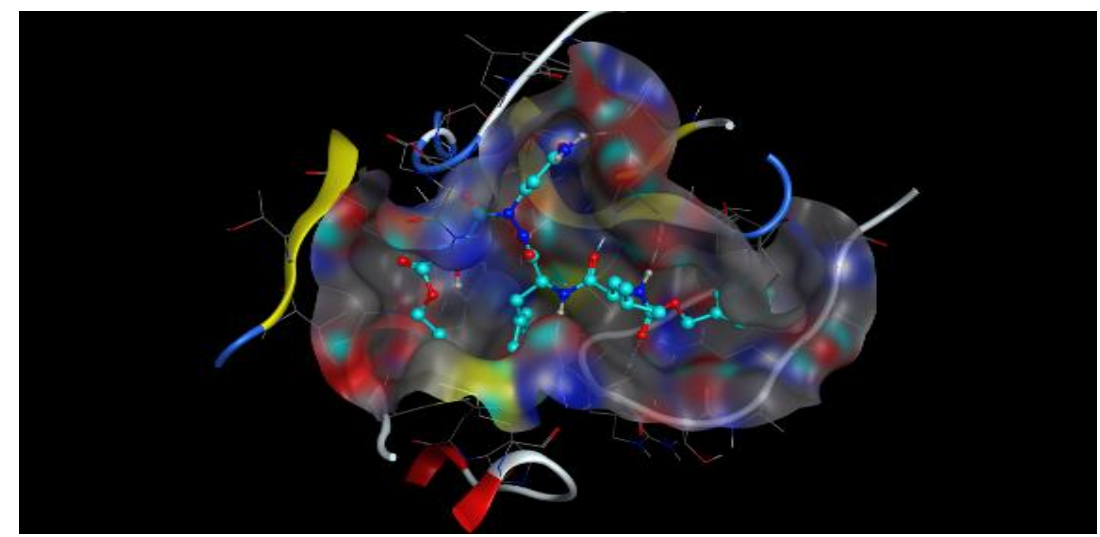

Figure 2: Isolated active site of SARS coronavirus main peptidase (PDB 2GTB) inhibited by an aza-peptide epoxide

\section{Docking and Building Complexes}

Docking using Dock module implanted in MOE, consists of positioning ligands into active site of 6LU7 and 2GTB with most of default tools to predict how molecules interacts with the binding site of the receptor ${ }^{\text {xlix }} 1$ li . First docked molecules series were proposed drugs and respective reference inhibitors (PRD_002214 of 6LU7 and AZP for 2GTB) in order to compare obtained score with score from chosen ligands of Nigella sativa $L$. Table 5 gives obtained scores by drugs under clinical test and inhibitor ligands (PRD_002214 and AZP). Table 6 shows scores of second docked ligand series from compounds from Nigella Sativa.

Table 5: Obtained docking score by drugs under clinical test and inhibitors.

\begin{tabular}{|c|c|c|c|}
\hline ligand & molecules & \multicolumn{2}{|c|}{ Score (Kcal/mol) } \\
\hline \multirow{2}{*}{$\begin{array}{c}\text { Reference } \\
\text { ligand }\end{array}$} & & 6LU7 & 2GTB \\
\cline { 2 - 4 } & PRD_002214 & -10.4669304 & -7.49913883 \\
\cline { 2 - 4 } & AZP & $/$ & -6.20844936 \\
\hline 1 & Chloroquine & -6.2930522 & -5.51465893 \\
\hline 2 & Hydroxychloroquine & -5.57386112 & -6.25860453 \\
\hline 3 & Azythromycine & -5.57062292 & -6.74997902 \\
\hline 4 & Arbidol & -7.15007734 & -7.07897234 \\
\hline 5 & Remdesivir & -6.35291243 & -4.12183571 \\
\hline 6 & Favipiravir & -4.23310471 & \\
\hline
\end{tabular}


Table 6: Obtained score from docking of Nigella Sativa compounds with 6LU7 and 2GTB

\begin{tabular}{|c|c|c|}
\hline Ligand & \multicolumn{2}{|c|}{ Score (kcal/mol) } \\
\hline & 6LU7 & 2GTB \\
\hline Nigellicine & -5.11696768 & -5.05794954 \\
\hline Nigellidine & -6.29734373 & -5.58170891 \\
\hline Nigellimine & -4.80306292 & -5.07316256 \\
\hline Carvacrol & -4.8290143 & -4.45325089 \\
\hline$\alpha$ - Hederin & -5.25583553 & -6.50204802 \\
\hline Thymol & -4.50417519 & -4.03594398 \\
\hline Thymoquinone & -4.71068573 & -4.41701126 \\
\hline Dithymoquinone & -4.45150137 & -4.99905396 \\
\hline thymohydroquinone & -4.22977924 & -4.23156166 \\
\hline
\end{tabular}

\section{Results and discussion}

Obtained results showed that Nigellidine gives the lowest energy $(-6.29734373 \mathrm{Kcal} / \mathrm{mol})$ in complex with 6LU7, which is the best score when compared to other docked compounds. Nigellidine gives score close to the one given by chloroquine $(-6.2930522 \mathrm{Kcal} / \mathrm{mol})$ and better score than hydroxychloroquine ($5.57386112 \mathrm{Kcal} / \mathrm{mol})$ and favipiravir $(-4.23310471 \mathrm{kcal} / \mathrm{mol})$. Nigellidine in complex with 6LU7 (Figure 3A and 3B) shows two hydrogen possible interactions with amino acid MET49 (H-donor) with a distance about $4.25 \AA$ and energy of $-0.7 \mathrm{Kcal} / \mathrm{mol}$ and $\pi-\mathrm{H}$ interaction with amino acid THR 190 with a distance about $4.24 \AA$ and energy of $-1.3 \mathrm{Kcal} / \mathrm{mol}$. Interactions between the rest of compounds from Nigella sativa and 6LU7 are reported in table 7.

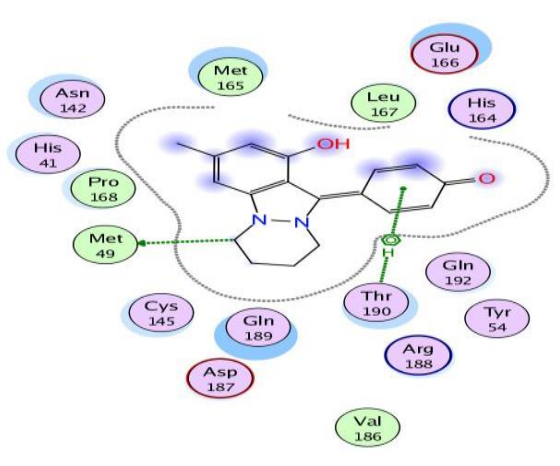

Figure 3A: 2D diagram interaction between Nigellidine and 6LU7

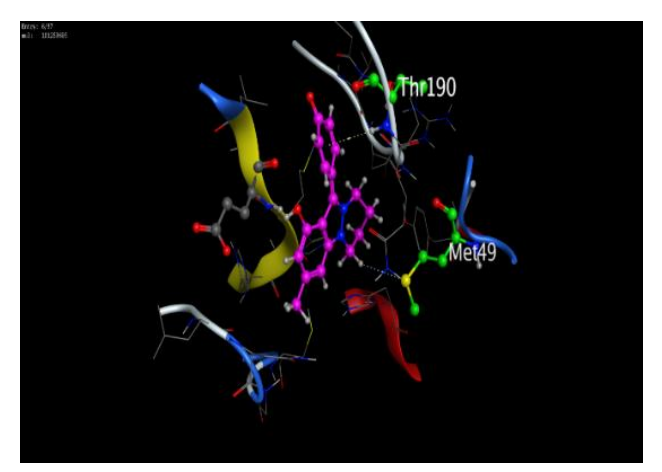

Figure 3B: 3D diagram interaction between Nigellidine and 6LU7

Docking results with 2 GTB show that $\alpha$ - Hederin gives better score $(-6.50204802 \mathrm{kcal} / \mathrm{mol})$ than chloroquine $(-6.20844936 \mathrm{kcal} / \mathrm{mol})$, hydroxychloroquine $(-5.51465893 \mathrm{kcal} / \mathrm{mol}))$ and favipiravir ($4.12183571 \mathrm{kcal} / \mathrm{mol}$ ). Alpha-hedrin in complex with 2GTB (figure 4A and 4B) show that only one hydrogen interaction (H-acceptor) with amino acid Gly 143 is possible with distance about $2.92 \AA$ and energy of $-2.2 \mathrm{Kcal} / \mathrm{mol}$.. Interactions between the rest of compounds from Nigella sativa and $2 \mathrm{GTB}$ are reported in table 9.

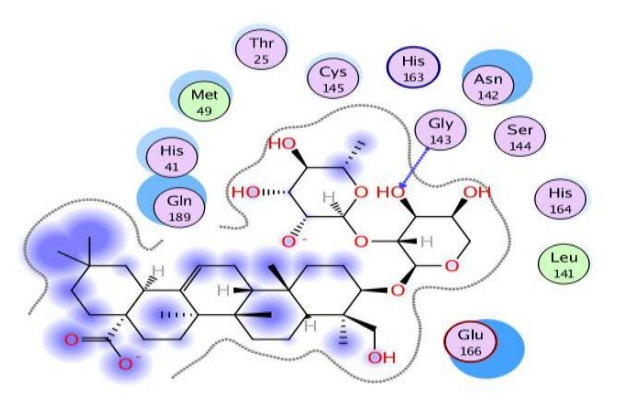

Figure 4A: 2D diagram interaction between $\alpha$ hederin and $2 \mathrm{GTB}$

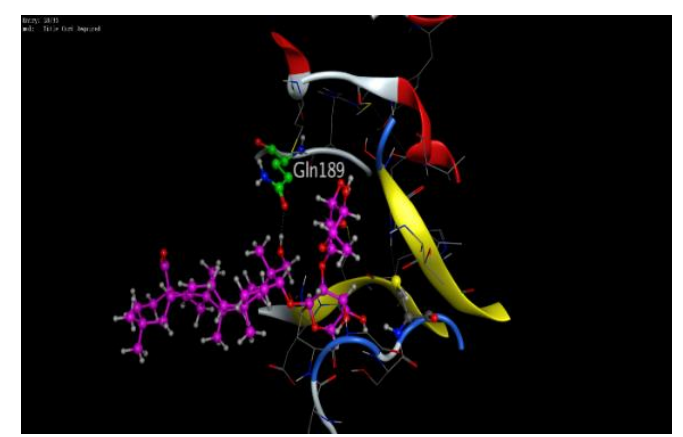

Figure 4A: 3D diagram interaction between $\alpha$ hederin and 2GTB 
Table 7: Interactions and 2D diagrams of compounds from Nigella Sativa with 6LU7

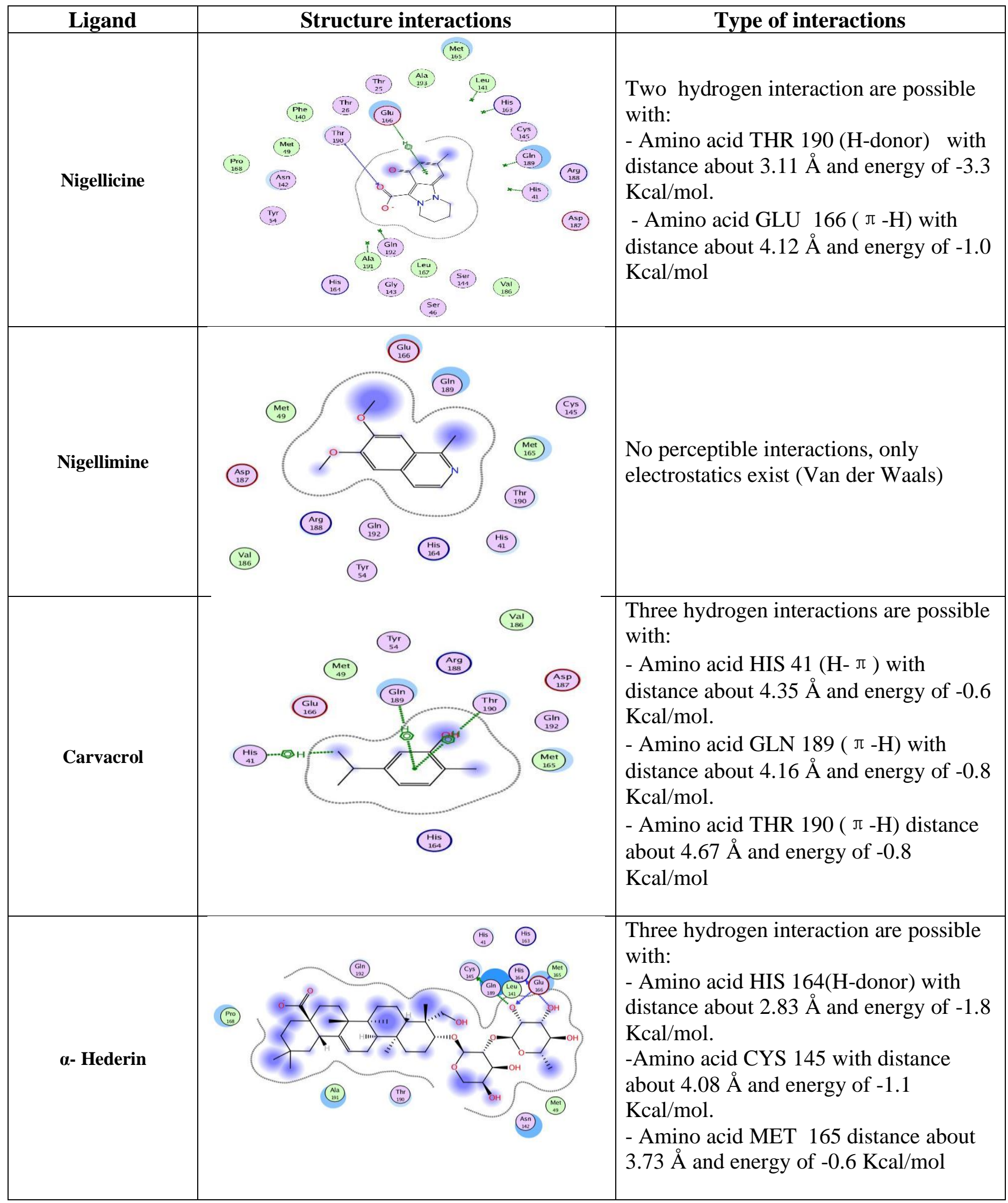




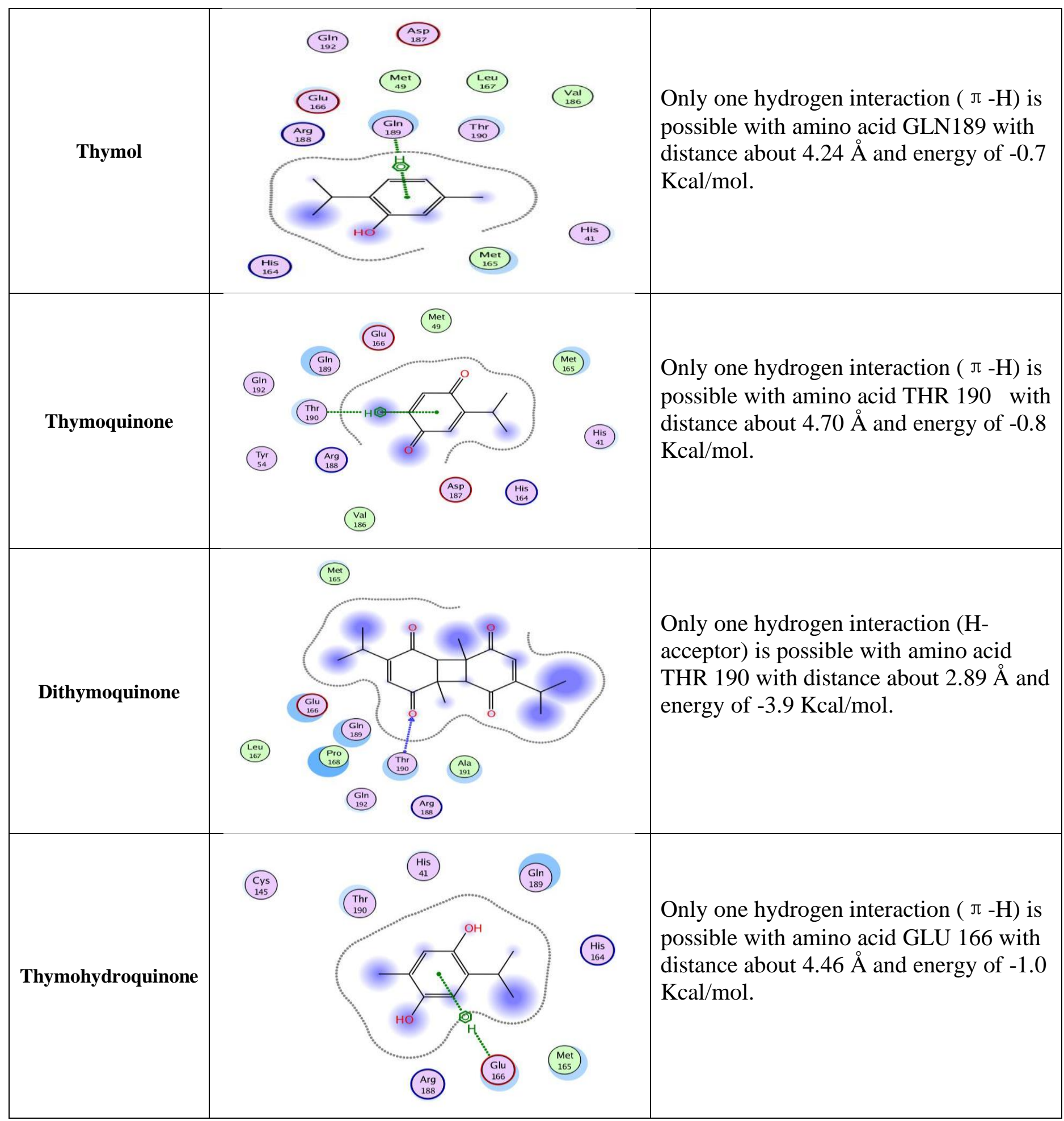


Table 8: Interactions and 2D diagrams of compounds from Nigella sativa with 2GTB

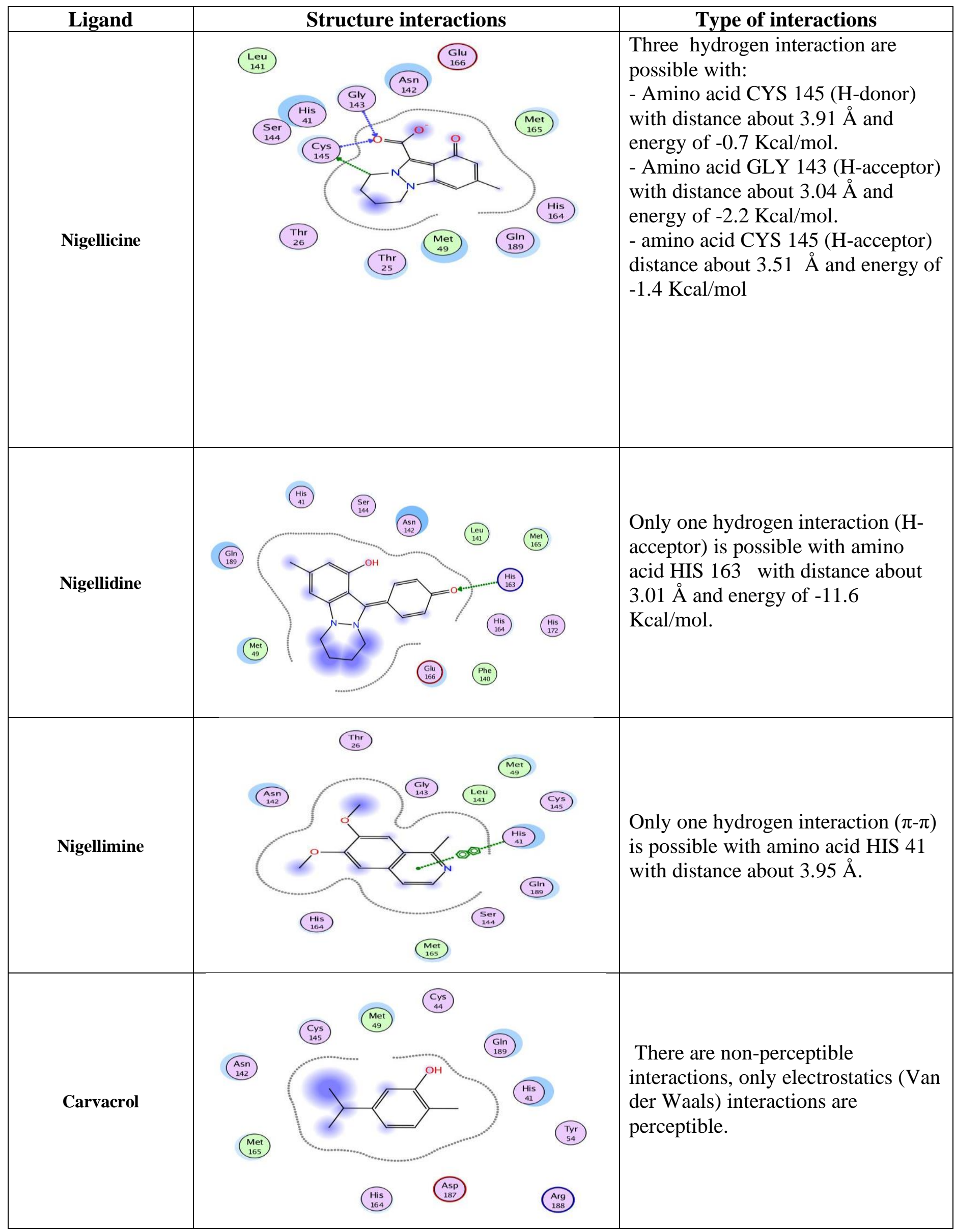




Dithymoquinone

\section{Conclusion}

The aim of the present study is to identify molecules from natural products which may inhibit COVID-19 by acting on the main protease $\left(\mathrm{M}^{\text {pro }}\right)$. Obtained results by molecular docking showed that Nigellidine and $\alpha$ hederin are main compounds from Nigella sativa which may inhibit COVID-19 giving the same or better energy score compared to drugs under clinical tests. Those results encourage further in vitro and in vivo investigations and also encourage traditional use of Nigella sativa preventively. 


\section{References}

i ‘WHO | World Health Organization', accessed 21 March 2020, https://www.who.int/home.

ii David S. Hui et al., 'The Continuing 2019-NCoV Epidemic Threat of Novel Coronaviruses to Global Health — The Latest 2019 Novel Coronavirus Outbreak in Wuhan, China', International Journal of Infectious Diseases 91 (February 2020): 264-66, https://doi.org/10.1016/j.ijid.2020.01.009.

iii Yashpal Singh Malik et al., 'Emerging Novel Coronavirus (2019-NCoV)—Current Scenario, Evolutionary Perspective Based on Genome Analysis and Recent Developments', Veterinary Quarterly 40, no. 1 (1 January 2020): 68-76, https://doi.org/10.1080/01652176.2020.1727993.

iv D. Paraskevis et al., 'Full-Genome Evolutionary Analysis of the Novel Corona Virus (2019-NCoV) Rejects the Hypothesis of Emergence as a Result of a Recent Recombination Event', Infection, Genetics and Evolution 79 (April 2020): 104212, https://doi.org/10.1016/j.meegid.2020.104212.

v 'WHO | World Health Organization'.

${ }^{v i}$ Deng-hai Zhang et al., 'In Silico Screening of Chinese Herbal Medicines with the Potential to Directly Inhibit 2019 Novel Coronavirus', Journal of Integrative Medicine 18, no. 2 (March 2020): 152-58, https://doi.org/10.1016/j.joim.2020.02.005.

vii Vijay G. Bhoj and Zhijian J. Chen, 'Ubiquitylation in Innate and Adaptive Immunity', Nature 458, no. 7237 (26 March 2009 ): 430-37, https://doi.org/10.1038/nature07959.

${ }^{\text {viii }}$ Marisa K. Isaacson and Hidde L. Ploegh, 'Ubiquitination, Ubiquitin-like Modifiers, and Deubiquitination in Viral Infection', Cell Host \& Microbe 5, no. 6 (18 June 2009): 559-70, https://doi.org/10.1016/j.chom.2009.05.012.

ix Prasenjit Mukherjee et al., 'Inhibitors of SARS-3CLpro: Virtual Screening, Biological Evaluation, and Molecular Dynamics Simulation Studies', Journal of Chemical Information and Modeling 51, no. 6 (27 June 2011): 1376-92, https://doi.org/10.1021/ci1004916.

${ }^{x}$ Wenhui Li et al., 'Angiotensin-Converting Enzyme 2 Is a Functional Receptor for the SARS Coronavirus', Nature 426, no. 6965 (27 November 2003): 450-54, https://doi.org/10.1038/nature02145.

xi 'RCSB PDB - 6LU7: The Crystal Structure of COVID-19 Main Protease in Complex with an Inhibitor N3', accessed 21 March 2020, http://www.rcsb.org/structure/6LU7.

xii 'Crystal Structures of the Novel Coronavirus Protease Guide Drug Development', Chemical \& Engineering News, accessed 28 March 2020, https://cen.acs.org/pharmaceuticals/drug-discovery/Crystal-structures-novel-coronavirus-protease/98/web/2020/03.

xiii Zhijian Xu et al., 'Nelfinavir Was Predicted to Be a Potential Inhibitor of 2019-NCov Main Protease by an Integrative Approach Combining Homology Modelling, Molecular Docking and Binding Free Energy Calculation', preprint (Pharmacology and Toxicology, 28 January 2020), https://doi.org/10.1101/2020.01.27.921627.

xiv Zhang et al., 'In Silico Screening of Chinese Herbal Medicines with the Potential to Directly Inhibit 2019 Novel Coronavirus'.

${ }^{x v}$ Siti Khaerunnisa et al., 'Potential Inhibitor of COVID-19 Main Protease (M ${ }^{\text {pro }}$ ) From Several Medicinal Plant Compounds by Molecular Docking Study', preprint (MEDICINE \& PHARMACOLOGY, 13 March 2020), https://doi.org/10.20944/preprints202003.0226.v1.

${ }^{x v i}$ Anh-Tien Ton et al., 'Rapid Identification of Potential Inhibitors of SARS-CoV-2 Main Protease by Deep Docking of 1.3 Billion Compounds', Molecular Informatics, 11 March 2020, minf.202000028, https://doi.org/10.1002/minf.202000028.

${ }^{x v i i}$ Chung-Hua Hsu et al., 'An Evaluation of the Additive Effect of Natural Herbal Medicine on SARS or SARS-Like Infectious Diseases in 2003: A Randomized, Double-Blind, and Controlled Pilot Study', Evidence-Based Complementary and Alternative Medicine 5, no. 3 (2008): 355-62, https://doi.org/10.1093/ecam/nem035.

${ }^{x v i i i}$ Mohsen Asadbeigi et al., 'Traditional Effects of Medicinal Plants in the Treatment of Respiratory Diseases and Disorders: An Ethnobotanical Study in the Urmia', Asian Pacific Journal of Tropical Medicine 7 (1 September 2014): S364-68, https://doi.org/10.1016/S1995-7645(14)60259-5.

xix Noureddine Chaachouay et al., 'Ethnobotanical and Ethnopharmacological Study of Medicinal and Aromatic Plants Used in the Treatment of Respiratory System Disorders in the Moroccan Rif', Ethnobotany Research and Applications 18, no. 0 (23 June 2019): 1-16.

${ }^{x x}$ Qiang Liu et al., 'Jiawei-Yupingfeng-Tang, a Chinese Herbal Formula, Inhibits Respiratory Viral Infections in Vitro and in Vivo', Journal of Ethnopharmacology 150, no. 2 (25 November 2013): 521-28, https://doi.org/10.1016/j.jep.2013.08.056.

xxi BOUREDJA Nadia, BOUTHIBA Meriem, and KEBIR Meriem, 'Ethnobotanical Study Of Medicinal Plants Used By Herbalists For The Treatment Of Respiratory Diseases In The Region Of Oran, Algeria’ 2, no. 1 (2020): 6.

xxii Ton et al., 'Rapid Identification of Potential Inhibitors of SARS-CoV-2 Main Protease by Deep Docking of 1.3 Billion Compounds'.

xxiii Xu et al., 'Nelfinavir Was Predicted to Be a Potential Inhibitor of 2019-NCov Main Protease by an Integrative Approach Combining Homology Modelling, Molecular Docking and Binding Free Energy Calculation'.

${ }^{x x i v}$ Liying Dong, Shasha Hu, and Jianjun Gao, 'Discovering Drugs to Treat Coronavirus Disease 2019 (COVID-19)', Drug Discoveries \& Therapeutics 14, no. 1 (2020): 58-60, https://doi.org/10.5582/ddt.2020.01012.

${ }^{x x v}$ Philippe Gautret et al., 'Hydroxychloroquine and Azithromycin as a Treatment of COVID-19: Results of an Open-Label NonRandomized Clinical Trial', International Journal of Antimicrobial Agents, 20 March 2020, 105949, https://doi.org/10.1016/j.ijantimicag.2020.105949.

${ }^{x x v i}$ Chemical, Computing Group Inc., and Chemical, Molecular Operating Environment (, version 2014 (1010 Sherbooke St. West, Suite \#910, Montreal, QC, Canada, H3A 2R7, 2014).

${ }^{x x v i i}$ Mohammad Tariq, 'Nigella Sativa Seeds: Folklore Treatment in Modern Day Medicine', Saudi Journal of Gastroenterology: Official Journal of the Saudi Gastroenterology Association 14, no. 3 (July 2008): 105-6, https://doi.org/10.4103/1319-3767.41725. 
xxviii Kiran Aqil et al., 'In Vitro Antiviral Activity of Nigella Sativa against Peste Des Petits Ruminants (PPR) Virus', Pakistan Journal of Zoology 50, no. 6 (October 2018), https://doi.org/10.17582/journal.pjz/2018.50.6.2223.2228.

${ }^{\text {xxix }}$ Mohaddese Mahboubi, 'Natural Therapeutic Approach of Nigella Sativa (Black Seed) Fixed Oil in Management of Sinusitis', Integrative Medicine Research 7, no. 1 (1 March 2018): 27-32, https://doi.org/10.1016/j.imr.2018.01.005.

${ }^{x x x}$ B. H. Ali and Gerald Blunden, 'Pharmacological and Toxicological Properties of Nigella Sativa', Phytotherapy Research 17, no. 4 (April 2003): 299-305, https://doi.org/10.1002/ptr.1309.

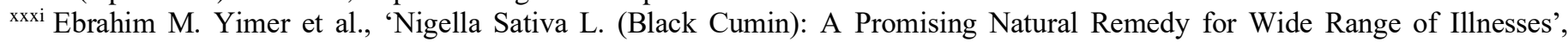
Evidence-Based Complementary and Alternative Medicine : ECAM 2019 (12 May 2019), https://doi.org/10.1155/2019/1528635.

xxxii 'RCSB PDB - 6LU7: The Crystal Structure of COVID-19 Main Protease in Complex with an Inhibitor N3'.

xxxiii 'RCSB PDB - 6LU7: The Crystal Structure of COVID-19 Main Protease in Complex with an Inhibitor N3'.

${ }_{\text {xxxiv }}$ T. W. Lee et al., 'Crystal Structures Reveal an Induced-Fit Binding of a Substrate-like Aza-Peptide Epoxide to SARS Coronavirus Main Peptidase.', J.Mol.Biol. 366 (2007): 916-32, https://doi.org/10.2210/pdb2gtb/pdb.

${ }^{\mathrm{xxxv}}$ Kourosh Hasanzadeh Ghahramanloo et al., 'Comparative Analysis of Essential Oil Composition of Iranian and Indian Nigella Sativa L. Extracted Using Supercritical Fluid Extraction and Solvent Extraction', Drug Design, Development and Therapy 11 (2017): 2221-26, https://doi.org/10.2147/DDDT.S87251.

xxxvi Nameer Khairullah Mohammed et al., 'The Effects of Different Extraction Methods on Antioxidant Properties, Chemical Composition, and Thermal Behavior of Black Seed (Nigella Sativa L.) Oil', Evidence-Based Complementary and Alternative Medicine: ECAM 2016 (2016): 6273817, https://doi.org/10.1155/2016/6273817.

xxxvii M. Akram Khan and M. Afzal, 'Chemical Composition of Nigella Sativa Linn: Part 2 Recent Advances', Inflammopharmacology 24, no. 2-3 (June 2016): 67-79, https://doi.org/10.1007/s10787-016-0262-7.

xxxviii Saima Amin et al., 'A Study of the Chemical Composition of Black Cumin Oil and Its Effect on Penetration Enhancement from Transdermal Formulations', Natural Product Research 24, no. $12 \quad$ (July 2010): 1151-57, https://doi.org/10.1080/14786410902940909.

${ }_{\text {xxxix }}$ L. Kokoska et al., 'Comparison of Chemical Composition and Antibacterial Activity of Nigella Sativa Seed Essential Oils Obtained by Different Extraction Methods', Journal of Food Protection 71, no. 12 (December 2008): 2475-80, https://doi.org/10.4315/0362-028x-71.12.2475.

${ }^{x 1}$ Kokoska et al.

xli PubChem, 'PubChem', accessed 30 March 2020, https://pubchem.ncbi.nlm.nih.gov/.

${ }^{x l i i}$ C. A. Lipinski et al., 'Experimental and Computational Approaches to Estimate Solubility and Permeability in Drug Discovery and Development Settings', Advanced Drug Delivery Reviews 46, no. 1-3 (1 March 2001): 3-26, https://doi.org/10.1016/s0169409x(00)00129-0.

xliii Christopher A. Lipinski, 'Lead- and Drug-like Compounds: The Rule-of-Five Revolution', Drug Discovery Today. Technologies 1, no. 4 (December 2004): 337-41, https://doi.org/10.1016/j.ddtec.2004.11.007.

xliv Belén García-Delgado Giménez et al., 'Evaluation of Blockbuster Drugs under the Rule-of-Five.', Die Pharmazie, 2010.

${ }^{x l v}$ Dong, Hu, and Gao, 'Discovering Drugs to Treat Coronavirus Disease 2019 (COVID-19)'.

xlvi Gautret et al., 'Hydroxychloroquine and Azithromycin as a Treatment of COVID-19'.

xlvii Vincent Madelain et al., 'Modeling Favipiravir Antiviral Efficacy against Emerging Viruses: From Animal Studies to Clinical Trials', CPT: Pharmacometrics \& Systems Pharmacology, 20 March 2020, https://doi.org/10.1002/psp4.12510.

xlviii Shinji Soga et al., 'Use of Amino Acid Composition to Predict Ligand-Binding Sites', Journal of Chemical Information and Modeling 47, no. 2 (April 2007): 400-406, https://doi.org/10.1021/ci6002202.

${ }^{x}$ lix Fernando D. Prieto-Martínez, Marcelino Arciniega, and José L. Medina-Franco, 'Acoplamiento Molecular: Avances Recientes y Retos', TIP Revista Especializada En Ciencias Químico-Biológicas 21, no. S1 (11 February 2019): 65-87.

1 Muthukumarasamy Karthikeyan and Renu Vyas, Practical Chemoinformatics (Springer India, 2014), https://doi.org/10.1007/978-81-322-1780-0.

li Christopher R. Corbeil, Christopher I. Williams, and Paul Labute, 'Variability in Docking Success Rates Due to Dataset Preparation', Journal of Computer-Aided Molecular Design 26, no. 6 (June 2012): 775-86, https://doi.org/10.1007/s10822-0129570-1. 